\title{
Pengaruh Model Pembelajaran
}

\section{Value Clarification Technique terhadap Nilai Kemandirian Siswa Kelas IV}

\author{
Mazidatur Rohmah ${ }^{1}$, Mohammad Zainuddin ${ }^{2}$, Sri Untari ${ }^{3}$ \\ ${ }^{1}$ Pendidikan Dasar-Universitas Negeri Malang \\ ${ }^{2}$ Keguruan Sekolah Dasar dan Prasekolah-Universitas Negeri Malang \\ ${ }^{3}$ Pendidikan Kewarganegaraan-Universitas Negeri Malang
}

\begin{tabular}{l}
\hline \hline INFO ARTIKEL \\
\hline Riwayat Artikel: \\
Diterima: $20-11-2019$ \\
Disetujui: $18-10-2020$ \\
\hline
\end{tabular}

\section{Kata kunci:}

the value of independence; value clarification technique; fourth grade students; nilai kemandirian; value clarification technique; siswa kelas IV

\author{
Alamat Korespondensi: \\ Mazidatur Rohmah \\ Pendidikan Dasar \\ Universitas Negeri Malang \\ Jalan Semarang 5 Malang \\ E-mail: mazida.mahsun@gmail.com
}

\section{ABSTRAK}

\begin{abstract}
This study aims to analyzed and described changes in value independence of fourth grade students who learn through value clarification technique and the students who learn conventional teaching. This quantitative research was conducted at SD Negeri Tanjungrejo 2 in Malang city with 81 students population. The number of samples in this research was 41 students for experiment group and 40 students for control group. The sample technique in this research was simple random sampling. The study used independent questionnaires to collect the data. The results of this study indicate the significant value of t-test 0.000 , this indicate that there was a significant effect value clarification technique to value student independence.
\end{abstract}

\begin{abstract}
Abstrak: Penelitian ini bertujuan untuk menganalisis dan mendeskripsikan perubahan nilai kemandirian siswa kelas IV yang belajar menggunakan value clarification technique dan siswa yang belajar dengan pembelajaran konvensional. Penelitian kuantitatif ini dilakukan di SD Negeri Tanjungrejo 2 di Kota Malang dengan 81 populasi siswa. Jumlah sampel pada penelitian ini adalah 41 siswa pada kelas eksperimen dan 40 siswa pada kelas kontrol. Teknik pengambilan sampel pada penelitian ini adalah simple random sampling. Pengumpulan data yang digunakan adalah angket kemandirian. Hasil penelitian ini menunjukkan nilai signifikansi uji-t adalah 0.000. Hal ini menunjukkan ada pengaruh signifikan value clarification technique terhadap nilai kemandirian siswa.
\end{abstract}

Undang-Undang Sisdiknas Nomor 20 Tahun 2003 pada Bab II pasal 3 menjelaskan bahwa salah satu fungsi pendidikan nasional adalah mengembangkan kemampuan dan membentuk watak kemandirian bagi warga negara. Keberhasilan pendidikan sangat erat kaitannya dengan peran sekolah dalam menjalankan tugasnya membentuk karakter bangsa yang sesuai dengan fungsi tersebut (Asiyai, 2013). Selain itu, Putri (2011) menjelaskan tempat strategis dalam membentuk karakter siswa adalah sekolah, hal ini karena peraturan di sekolah memberikan aturan di segala hal, baik perilaku maupun ucapan siswa. Oleh karena itu, pendidikan karakter harus ditanamkan sejak dini dalam diri siswa. Pentingnya pendidikan karakter memang tidak diragukan lagi, hal ini karena banyak sekali kasus penurunan karakter yang mewarnai dunia pendidikan Indonesia.

Pendidikan karakter dilatarbelakangi oleh masalah sosial yang disebabkan oleh remaja, seperti perundungan dan kecurangan. Selain itu, pendidikan karakter juga perlu didukung dengan pengetahuan tentang nilai yang baik, adanya keinginan melakukan nilai tersebut, dan action dengan nilai tersebut (Buchori, Setyosari, Dasna \& Ulfa, 2016). Pendidikan karakter ialah sebuah proses penanaman nilai karakter baik dengan memberikan latihan klarifikasi nilai baik dan buruk pada siswa agar siswa memiliki perilaku sesuai dengan nilai-nilai baik yang berlaku di masyarakat (Mehlig \& Milson, 2002). Tujuan pendidikan karakter agar siswa memiliki karakter baik. Karakter baik adalah sebuah konsep tentang pengetahuan yang baik dan diimplementasikan dalam perbuatan yang baik pula (Ozturk, 2011). Pendidikan karakter perlu diterapkan sejak kecil, khususnya saat siswa sedang menempuh jenjang pendidikan sekolah dasar. Penerapan pendidikan karakter di sekolah dasar sangat penting. Sejalan dengan hal tersebut Tannir \& Al-Hroub (2013) menjelaskan pendidikan karakter memiliki pengaruh di sekolah dasar, yaitu memberikan hasil dalam jangka waktu yang panjang pada pandangan positif siswa tentang menilai diri mereka sendiri dan sekolah. 
Pendidikan dasar menjadi lembaga formal yang berperan penting sebagai upaya peningkatan sumber daya manusia sejak dini (Faridi, 2014). Pendidikan karakter di sekolah dasar tidak terlepas dari peran serta guru. Keberhasilan pendidikan karakter dipengaruhi oleh keefektifan guru dalam menerapkannya, kepercayaan diri guru dalam mengajarkan karakter dan memberikan teladan yang baik menjadi kunci utama penerapan pendidikan karakter (Prestwich, 2004). Selain itu, keberhasilan pembelajaran bergantung dengan kelihaian guru dalam menyampaikan materi sehingga siswa mampu mengerti dan memahami materi yang dipelajari (Tarigan, 2019). Keseriusan pemerintah dalam menanamkan karakter siswa dibuktikan dengan diberlakukannya kurikulum 2013. Penerapan kurikulum 2013 menitikberatkan pada pendidikan karakter siswa. sehingga pengajaran difokuskan untuk mendorong siswa memahami nilai moral dan bersikap dengan nilai yang benar (Rachmadtullah, 2018). Pendidikan karakter pada kurikulum 2013 dibantu oleh PPK (Penguatan pendidikan karakter) yang disahkan dalam Perpres No.87 tahun 2017 tentang PPK. Gerakan PPK yang dibuat oleh pemerintah merupakan wujud keseriusan pemerintah dalam memperkuat karakter anak bangsa yang kian rusak akibat perkembangan zaman (Haidar, 2017). Program PPK menanamkan lima nilai pada siswa, salah satunya adalah nilai kemandirian. Kemandirian adalah cerminan sikap dan perilaku manusia sebagai hasil dari akomodasi sifat-sifat baiknya yang digunakan dalam berperilaku (Wijaya, 2015). Selain itu, Kemandirian adalah sikap percaya diri yang dimiliki siswa untuk bertanggung jawab atas apa yang dihadapi dan dilakukan serta dalam mengambil keputusan (Rini, 2012). Karakter mandiri adalah sikap siswa yang memiliki kemampuan memutuskan sendiri apa yang seharusnya dikerjakan tanpa bantuan orang lain dalam mengerjakan tugas (Wardono, Waluya, Kartono, Mulyono, \& Mariani, 2017). Siswa mampu menjadi individu yang mandiri dengan pendidikan nilai, karena dengan berpikir dan menemukan pemecahan masalah, siswa mampu bertanggung jawab pada diri sendiri (Bandono \& Fahyuni, 2017).

Usaha pembentukan watak kemandirian siswa bukan hanya disekolah, namun juga harus ada peran serta semua pihak, yaitu keluarga dan masyarakat. Pribadi siswa yang berkarakter akan ditentukan oleh faktor lingkungan, jika lingkungan berkarakter, maka akan memberikan kebiasaan-kebiasaan baik pada siswa hingga menjadi siswa yang berkarakter pula (Wening 2012). Upaya pendidikan karakter perlu dilakukan oleh berbagai pihak, yaitu sekolah dan masyarakat. Upaya kolaboratif tersebut harus bersinergi dalam memerangi kemerosotan moral (Beachum, 2005). Sistem pendidikan harus memberikan kesadaran nilai bagi siswa, orangtua, dan masyarakat. Hal ini dilakukan untuk memberikan solusi atas permasalahan yang terjadi pada anak-anak, baik siswa sebagai korban maupun pelaku (Kahil \& El Hassan, 2005).

Kemandirian siswa bukan hanya diperlukan untuk menghadapi permasalahan sehari-hari, namun lebih kompleks dari itu. Kedepan, siswa akan dihadapkan pada tantangan perkembangan zaman yang jauh lebih rumit dari pendulunya. Hal ini karena teknologi berkembang sangat cepat seiring bergantinya zaman. Eksistensi teknologi semakin terlihat dari masa ke masa, khususnya pada abad 21 ini. Penggunaan internet sebagai sumber dan media pembelajaran telah dilakukan di banyak sekolah (Nasution, 2018). Indoensia tengah menghadapi tantangan abad 21 yang merambah ke berbagai bidang, tak terkecuali pendidikan, maka diperlukan peningkatan kompetensi siswa sejak jenjang pendidikan dasar untuk meletakkan dasar kognitif, afektif dan psikomotorik pada siswa (Susanto, Sa'dijah, \& Gipayana, 2016). Dalam menghadapi tantangan abad 21 bahwa pendidikan karakter bukan hanya sebagai slogan, namun harus tertanam dengan baik di sekolah serta dipraktikkan oleh berbagai kalangan, baik orang tua, sekolah, maupun masyarakat, semuanya harus bersinergi untuk menanamkan nilai baik pada diri siswa (Singh, 2019). Siswa perlu dibekali pendidikan karakter dalam menghadapi tantangan internet of thinks (IoT) di abad 21 ini agar memiliki kemampuan menyaring informasi yang didapatkannya dari berbagai sumber (Soetantyo, 2012).

Berdasarkan hasil wawancara dan observasi di lapangan, diperoleh data berupa hasil wawancara dan obsevasi dengan guru kelas IV. Hasilnya adalah nilai kemandirian siswa perlu ditingkatkan dan model pembelajaran yang digunakan perlu mengintegrasikan pendidikan karakter. Hal ini menjadi permasalahan karena terjadi kesenjangan dengan kondisi ideal, yaitu model pembelajaran harusnya mengintegrasikan pendidikan karakter dan nilai kemandirian menjadi sebuah pembiasaan di sekolah, khususnya di kelas. Karakter siswa hanya mampu dikembangkan jika menggunakan instrumen pendidikan yang tepat, salah satunya adalah model pembelajaran yang tepat (Fauzi, Zainuddin, Atok, 2017). Model pembelajaran yang sesuai akan memudahkan guru dan siswa memahami sebuah nilai dan menjadikan pembelajaran aktif, reflektif, dan bertanggung jawab (Burwell, 2005). Siswa akan dengan mudah meningkatkan kemampuannya dan mengatasi kelemahannya jika ia ditempatkan di lingkungan yang mendukung (Larkin, 2001). Tak terkecuali pada karakter kemandirian yang perlu dikembangkan dengan model pembelajaran yang sarat akan nilai. Model pembelajaran tersebut adalah value clarification technique. Value clarification technique adalah suatu pendekatan yang membantu siswa untuk menemukan nilai pada dirinya sebagai bekal untuk menentukan arah dan tujuan hidupnya sendiri untuk hidupnya (Brady, 2010).

Proses terpenting dalam menilai sesuatu adalah klarifikasi nilai. Dimana di dalam proses klarifikasi tersebut siswa diarahkan untuk berani memilih dan bertanggungjawab pada pilihannya untuk menyelesaikan permasalahan dilema moral yang ia temui sehari-hari (Husu \& Tirri, 2007). Model pembelajaran value clarification technique pertama kali digunakan oleh Louis Raths tahun 1950-an dengan tujuan membantu siswa menemukan nilai dalam dirinya (Rochani, 2017). Tujuan model pembelajaran value clarification technique adalah memberikan pengalaman pada siswa untuk mencari dan menemukan sendiri sebuah nilai, dimana nilai tersebut kemudian disesuaikan dengan nilai yang telah melekat pada dirinya, hasil nilai tersebut akan digunakan untuk mencari solusi permasalahan yang dihadapi (Ekasari, 2017). Value clarification technique bertujuan untuk memeriksa ulang nilai yang ada dalam diri siswa karena seiring dengan bertambahnya pengalaman, maka siswa akan mengadopsi nilai-nilai baru (Scheetz \& Easterbrooks, 2004). Langkah pembelajaran value clarification technique memiliki tujuh tahap, diantaranya (1) kebebasan memilih, yaitu menentukan pilihan yang dianggap baik, dan memilih alternatif, dan 
memilih setelah mempertimbangkan baik dan buruknya, (2) menghargai, yaitu merasa bangga akan pilihannya dan berani mengakuinya di depan umum, (3) berbuat, yaitu mau dan mencoba melaksanakan pilihannya dalam bentuk perbuatan, dan menjadikan nilai tersebut sebuah kebiasaan dalam hidupnya sehari-hari (Masruri \& Mursetyadi, 2014). Pendidikan karakter dapat dilakukan dengan banyak cara, salah satunya adalah dengan klarifikasi nilai. Melalui klarifikasi nilai, siswa diberikan kesempatan untuk menyadari nilai yang ada dalam diri mereka sendiri dan membantu siswa dalam menentukan nilai yang baik untuk dirinya (Smith \& Bryan, 1973). Value clarification technique memungkinkan siswa memiliki nilainya sendiri walaupun berbeda dengan orang lain selama nilai tersebut mampu mengarahkan siswa menjadi pribadi yang terarah, lebih produktif dan memiliki kesadaran sosial (Brady, 2010).

Penelitian dengan model pembelajaran serupa, yaitu value clarification technique pernah dilakukan oleh Emmett \& Mosconi (2003) yang hasilnya Value Clarification dapat dijadikan alternatif sebagai upaya konselor dalam mengembangkan karir siswa. Sementara itu, penelitian Sulastri, Budimansyah, \& Sopandi (2015) hasilnya penerapan value clarification technique memberikan pengaruh sangat baik pada siswa, yaitu pada kesadaran lingkungan dan meningkatkan kemampuan komunikasi yang lebih baik pada siswa. Penelitian lain juga dilakukan oleh Guthrie \& Fritz (2017) hasilnya value clarification technique membantu siswa mengidentifikasi dan mengklarifikasi nilai dalam dirinya untuk menjadi pemimpin yang memiliki etika dan dibutuhkan baik hari ini maupun dimasa yang akan datang. Berdasarkan permasalahan tersebut, maka diperlukan penelitian untuk mengetahui pengaruh model pembelajaran value clarification technique terhadap nilai kemandirian siswa.

\section{METODE}

Penelitian ini merupakan penelitian kuantitatif yang dilakukan untuk mengetahui pengaruh model pembelajaran value clarification technique terhadap nilai kemandirian siswa. Rancangan pada penelitian ini adalah quasi experimental desain dengan menggunakan non equivalent control grup design. Dimana terdapat dua kelompok pada penelitian ini, yaitu kelompok eksperimen yang menggunakan model pembelajaran value clarification technique dan kontrol dengan pembelajaran konvensional, serta dilakukan pretest dan posttest sebelum dan sesudah perlakuan. Populasi pada penelitian ini adalah siswa kelas IV SD Negeri Tanjungrejo 2, dan kelas IVA dan IVB sebagai sampelnya. Adapun desain penelitian dapat dilihat pada gambar 1 .

\begin{tabular}{|c|c|c|}
\hline $\mathrm{O}_{1}$ & $\mathrm{X}$ & $\mathrm{O}_{2}$ \\
\hline $\mathrm{O}_{1}$ & - & $\mathrm{O}_{2}$ \\
\hline
\end{tabular}

\section{Gambar 1. Desain Penelitian non equivalent control grup design}

\section{Keterangan: \\ $\mathrm{O}_{1}$ : Pelaksanaan Pretest \\ $\mathrm{O}_{2}$ : Pelaksanaan Posttest \\ $\mathrm{X}$ : Perlakuan}

Teknik pengambilan sampel dilakukan dengan simple random sampling, dan diperoleh ketentuan bahwa kelas IVA sebagai kelas eksperimen dan IVB sebagai kelas kontrol. Teknik pengumpulan data pada penelitian ini adalah angket kemandirian siswa. Nilai kemandirian terdiri dari beberapa subnilai, diantaranya (1) kerja keras, (2) tangguh tahan banting, (3) daya juang, (4) profesional, (5) kreatif, (6) keberanian, dan (7) menjadi pembelajar sepanjang hayat. Dari beberapa subnilai tersebut, lalu dikembangkan menjadi beberapa soal pernyataan yang harus dijawab siswa. Daftar pernyataan berjumlah 33 soal dalam bentuk daftar cocok (checklist). Terdapat tiga rentang skor yang digunakan dalam penelitian ini, yaitu (1) skor satu berarti salah, maksudnya siswa tidak merasa berperilaku sesuai pernyataan tersebut, (2) skor dua berarti benar, maksudnya siswa merasa berperilaku sesuai dengan pernyataan tersebut, dan (3) skor tiga berarti sangat benar, maksudnya siswa merasa benar-benar melakukan apa yang ada dalam pernyataan tersebut tanpa ada keraguan. Angket kemandirian siswa di sebarkan sebelum dilakukan pembelajaran (pretest), disetiap akhir pembelajaran selama penelitian berlangsung, setelah semua perlakuan selesai dilakukan (posttest), baik pada kelas eksperimen maupun kelas kontrol. Namun pada uji hipotesis, data yang digunakan adalah hasil pretest dan posttest kelas eksperimen saja. Uji hipotesis yang dilakukan dalam penelitian ini adalah uji-t dengan angket kemandirian siswa sebagai datanya. Uji ini dibantu dengan SPSS 22 for windows, ketentuannya adalah jika nilai sig. < 0.000 maka terdapat pengaruh signifikan model pembelajaran value clarification technique terhadap nilai kemandirian siswa.

\section{HASIL}

Penelitian ini dilaksanakan di SD Negeri Tanjungrejo 2 Kota Malang. Penerapan model pembelajaran value clarification technique dilakukan di kelas IVA dan pembelajaran konvensional di kelas IVB. Penelitian ini fokus kepada muatan mata pelajaran Pendidikan Kewarganegaraan (PKn) khususnya pada Kompetensi Dasar 2.4 Menampilkan sikap kerja sama dalam berbagai bentuk keberagaman suku bangsa, sosial, dan budaya di Indonesia yang terikat persatuan dan kesatuan. Dari 
Kompetensi Dasar 2.4 tersebut kemudian dikembangkan menjadi indikator kemandirian. Pada dasarnya penelitian ini berangkat dari indikator. Pengambilan data pada penelitian ini dilaksanakan sebanyak tiga kali pembelajaran, baik di kelas eksperimen maupun kelas kontrol. Sebelum pengambilan data, angket kemandirian siswa diuji coba terlebih dahulu untuk mengetahui validitas dan reliabilitas angket. Berdasarkan hasil uji coba angket yang dilakukan, diperoleh 30 data yang valid dan instrumen juga dikatakan reliabel karena diperoleh nilai 0,872 dengan kategori sangat tinggi. Setelah lolos uji validitas dan reliabilitas, maka hasil angket kemandirian siswa kemudian diuji normalitas dan homogenitasnya. Hasil uji normalitas data angket kemandirian siswa yang dihitung menggunakan Kolmogorov Smirnov sebagaimana ditunjukkan pada tabel 1.

Tabel 1. Hasil Uji Normalitas Angket Kemandirian Siswa

\begin{tabular}{clccc}
\hline & \multirow{2}{*}{ Kelas } & \multicolumn{3}{c}{ Kolmogorov-Smirnov } \\
\cline { 3 - 5 } & & Statistic & df & Sig. \\
\hline \multirow{3}{*}{ Nilai } & pretest ekperimen (model vct) & .136 & 40 & .060 \\
Kemandirian & posttest eksperimen (model vct) & .125 & 40 & .115 \\
& pretest kontrol (konvensional) & .127 & 41 & .093 \\
& posttest kontrol (konvensional) & .123 & 41 & .124 \\
\hline
\end{tabular}

Berdasarkan tabel di atas, data nilai kemandirian siswa pada posttest dam pretest kelas eksperimen serta posttest dan pretest kelas kontrol diperoleh hasil semua data berdistribusi normal karena nilai sig.di atas 0,05. Setelah uji normalitas, maka dilakukan uji homogenitas. Berikut ini hasil uji homogenitas (tabel 2).

Tabel 2. Hasil Uji Homogenitas Angket Kemandirian Siswa

\begin{tabular}{cccc}
\hline Levene Statistic & df1 & df2 & Sig. \\
\hline .660 & 1 & 79 & .419 \\
\hline
\end{tabular}

Berdasarkan tabel di atas, maka dapat ditarik kesimpulan bahwa data angket kemandirian siswa homogen, hal ini dibuktikan dengan nilai sig. > 0.05, yaitu 0.419. Setelah data dinyatakan normal dan reliabel, maka dilakukan uji hipotesis. Uji hipotesis yang digunakan adalah uji-t. Hasil uji-t dijelaskan pada tabel 3.

Tabel 3. Hasil Uji-T Nilai Kemandirian Siswa

\begin{tabular}{|c|c|c|c|c|c|c|c|c|c|}
\hline & & \multicolumn{5}{|c|}{ Paired Differences } & \multirow[b]{3}{*}{$\mathbf{T}$} & \multirow{3}{*}{\multicolumn{2}{|c|}{ df Sig. (2-tailed) }} \\
\hline & & \multirow[b]{2}{*}{ Mean } & \multirow{2}{*}{$\begin{array}{c}\text { Std. } \\
\text { Deviation }\end{array}$} & \multirow{2}{*}{$\begin{array}{l}\text { Std. Error } \\
\text { Mean }\end{array}$} & \multicolumn{2}{|c|}{$\begin{array}{l}\text { 95\% Confidence Interval of } \\
\text { the Difference }\end{array}$} & & & \\
\hline & & & & & Lower & Upper & & & \\
\hline Pair 1 & $\begin{array}{l}\text { Pre Test } \\
\text { Eksperimen - } \\
\text { Posttest } \\
\text { Eksperimen }\end{array}$ & -5.675 & 4.548 & .719 & -7.130 & -4.220 & -7.891 & 39 & .000 \\
\hline
\end{tabular}

Berdasarkan uji-t yang telah dilakukan, maka dapat disimpulkan bahwa terdapat pengaruh signifikan model pembelajaran value clarification technique terhadap nilai kemandirian siswa. Kemandirian siswa memiliki tujuh sibnilai, yaitu (1) kerja keras, (2) tangguh tahan banting, (3) daya juang, (4) profesional, (5) kreatif, (6) keberanian, dan (7) menjadi pembelajar sepanjang hayat. Berdasarkan data posttest hasil angket kemandirian siswa, diperoleh nilai tertinggi dan terendah sebagaimana ditunjukkan pada gambar 2.

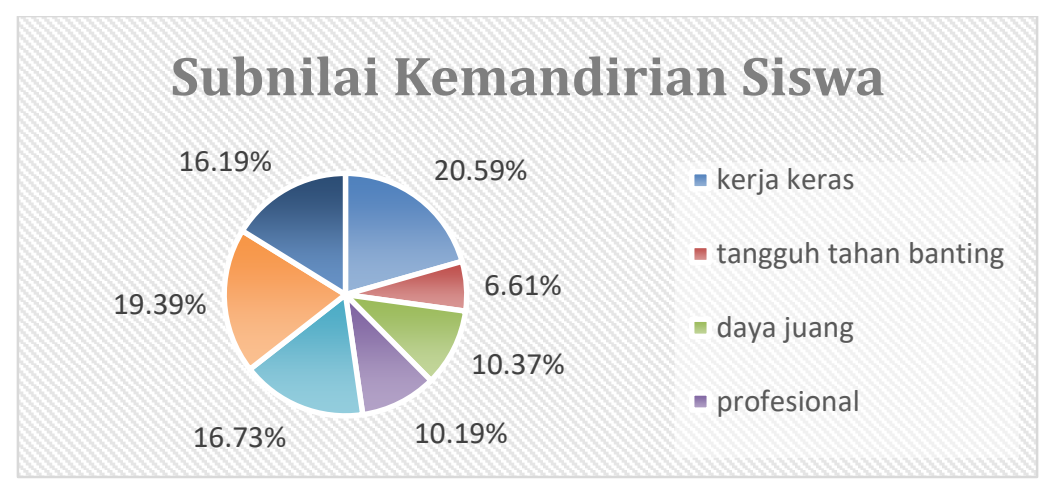

Gambar 2. Hasil Subnilai Kemandirian Siswa 


\section{PEMBAHASAN}

Peningkatan nilai kemandirian siswa dipengaruhi oleh beberapa faktor, salah satunya model pembelajaran value clarification technique. Model pembelajaran value clarification technique adalah suatu pendekatan yang membantu siswa untuk menemukan nilai pada dirinya sebagai bekal untuk menentukan arah dan tujuan hidupnya sendiri untuk hidupnya (Brady, 2010). Model ini bertujuan untuk memberikan pengalaman pada siswa untuk mencari dan menemukan sendiri sebuah nilai, dimana nilai tersebut kemudian disesuaikan dengan nilai yang telah melekat pada dirinya, hasil nilai tersebut akan digunakan untuk mencari solusi permasalahan yang dihadapi (Ekasari, 2017). Melalui model pembelajaran value clarification technique, nilai kemandirian siswa dihitung menggunakan instrumen pengukuran, yaitu angket nilai kemandirian siswa. Hasil angket nilai kemandirian siswa dalam penelitian ini menunjukkan bahwa subnilai kemandirian siswa yang sangat meningkat adalah nlai kerja keras dengan presentase 20,59. Hal ini bukan tanpa alasan karena teknik pengajaran dalam value clarification technique yang digunakan dalam pembelajaran adalah permainan yang menantang sehingga siswa terdorong untuk memiliki subnilai kerja keras.

Selain subnilai yang meningkat, hasil uji hipotesis yaitu uji-t menunjukkan bahwa terdapat pengaruh model pembelajaran value clarification technique terhadap nilai kemandirian siswa di SDN Tanjungrejo 2, hal ini dibuktikan dengan nilai sig.0,00. Keberhasilan model pembelajaran value clarification technique dalam memengaruhi nilai kemandirian, selain dibantu dengan kegiatan yang menantang dan sarat akan nilai, namun juga tidak terlepas dari peran guru. Guru memegang peranan penting dalam penerapan model pembelajaran ini. Hal ini karena letak "klarifikasi" yang dimaksud disini adalah setelah pembelajaran selesai, guru memberikan klarifikasi nilai yang diperoleh dari kegiatan pembelajaran tersebut. Sehingga keberhasilan model pembelajaran value clarification technique ini sangat dipengaruhi oleh kemampuan guru dalam mengelola kelas dan memberikan klarifikasi semudah mungkin untuk dipahami siswa.

Penelitian dengan nilai kemandirian juga pernah dilakukan oleh Sumliyah (2017) menunjukkan bahwa adanya pengaruh positif signifikan karakter kemandirian setelah menerapkan model pembelajaran value clarification technique. Hasilnya memang sama-sama menunjukkan peningkatan dalam nilai kemandirian, namun instrumen yang digunakan berbeda dan hasilnya tentu berbeda. dalam penelitian ini, peningkatan nilai kemandirian ditandai dengan peningkatan ketujuh subnilai kemandirian siswa. Perbedaannya juga terletak pada subjek penelitian, yaitu penelitian ini menerapkan model pembelajaran value clarification technique di jenjanng pendidikan dasar, yaitu siswa SD. Hal ini membuktikan bahwa model pembelajaran VCT bukan hanya bisa diterapkan di perguruan tinggi atau siswa SMA, namun juga siswa sekolah dasar. Jadi, dapat disimpulkan bahwa terdapat persamaan penelitian terdahulu dengan penelitian ini.

Penelitian dengan model yang sama juga pernah dilakukan oleh Emmett \& Moscon (2003) yang hasilnya Value Clarification dapat dijadikan alternatif sebagai upaya konselor dalam mengembangkan karir siswa. hasil penelitian tersebut membuktikan bahwa model pembelajaran value clarification technique dapat dipakai untuk berbagai tujuan, salah satunya adalah karir siswa. berbeda dengan penelitian ini yang menggunakan model value clarification technique untuk meningkatkan nilai kemandirian siswa. Selain itu, hasil penelitian Sulastri, Budimansyah, \& Sopandi (2015) penerapan value clarification technique memberikan pengaruh sangat baik pada siswa, yaitu pada kesadaran lingkungan dan meningkatkan kemampuan komunikasi yang lebih baik pada siswa. Selain meningkatkan karir siswa, model value clarification technique ternyata juga mampu meningkatkan kesadaran lingkungan dan komunikasi siswa. Berbeda dengan kedua penelitian tersebut, penelitian ini berfokus pada pengembangan nilai, yaitu nilai kemandirian. Selain itu, Azmi, Degeng, Kamdi, \& Setyosari (2018) menjelaskan bahwa hasil penelitiannya menunjukkan model pembelajaran value clarification technique mampu meningkatkan sikap, karakter, dan moral siswa. Dengan demikian, dapat disimpulkan hasil penelitian terdahulu berbeda dengan penelitian ini karena pengaruh value clarification technique masih kepada karakter umum, sedangkan penelitian ini hanya berfokus pada nilai kemandirian saja.

\section{SIMPULAN}

Penerapan model pembelajaran value clarification technique terbukti memberikan pengaruh yang signifikan terhadap nilai kemandirian siswa kelas IV di SD Negeri Tanjungrejo 2 Kota Malang. Hal ini dibuktikan dengan hasil uji-t dengan nilai sig. 0.000. Selain itu, berdasarkan data hasil angket kemandirian siswa, hasil nilai kemandirian siswa meningkat. Berikut ini urutan dari yang tertinggi hingga terendah, yaitu (1) kerja keras, (2) keberanian, (3) kreatif, (4) menjadi pebelajar sepanjang hayat, (5) daya juang, (6) profesional, dan (7) tangguh tahan banting. Hal ini juga terlihat pada proses pembelajaran, siswa cenderung meminta tambahan waktu ketika belum selesai dan semua terlihat aktif dalam mengemukakan pendapat ketika diskusi berlangsung. Model pembelajaran value clarification technique dapat dijadikan alternatif bagi guru untuk meningkatkan nilai kemandirian siswa. Penerapan model pembelajaran value clarification technique juga memerlukan kemampuan yang baik oleh guru sehingga mampu menerapkan model pembelajaran value clarification technique dengan baik dan sesuai sintaks. 


\section{DAFTAR RUJUKAN}

Asiyai. (2013). Challenges of Quality in Higher Education in Nigeria in the $21^{\text {st }}$ Century. International Journal of Educational Planning \& Administration, 3(2), 159-172.

Azmi, S., Degeng, I. N. S., Kamdi, W., \& Setyosari, P. (2018). The Effect of Value Clarification Learning Strategies and Social Inquiry on Concept Comprehension and Student Tolerance Attittudes with Different Cognitive Style. International Journal of Civil Engineering and Technology, 9(11), 1072-1083.

Bandono, A \& Fahyuni, E. F. (2017). The Use of Value Clarification Technique-Based-Picture Story Media as an Alternative Media to Value Education in Primary School. Harmonia: Journal of Arts Research and Education, 17(1), 68-74.

Beachum, F. D. (2005). Changes and Transformations in the Philosophy of Character Education in the $20^{\text {th }}$ Century. Essays in Education, 14(14), 1-7.

Brady, L. (2010). Values Clarification in Values Education: A Critiquetle. Educational Practice and Theory, 32(2), $23-31$.

Buchori, A., Setyosari, P., Dasna, I. W., \& Ulfa, S. (2016). Developing Character Building Learning Model Using Mobile Augmented Reality on Elementary School Student in Central Java. Global Journal of Pure and Applied Mathematics, 12(4), 3433-3444.

Burwell, K. (2005). A Degree of Independence: Teachers' Approaches to Instrumental Tuition in a University College. British Journal of Music Education, 22(3),199-215.

Ekasari, P. N. (2017). Pembelajaran Berbasis Nilai pada Mata Pelajaran Sejarah Melalui Model VCT (Value Clarification Technique). Jurnal Sejarah Budaya, dan Pengajarannya, 11(2), 192-198.

Emmett, J., \& Mosconi, J. (2003). Effects of a Values Clarification Curriculum on High School Students' Definitions of Success." Professional School Counseling, 7(2), 68-78.

Faridi, A. (2014). The Difficulties of English Teachers In Instilling Character Building Through Narrative Stories At Elementary Schools In Central Java, Indonesia. International Journal of Contemporary Applied Sciences, 1(2), 68-82.

Fauzi, A. R., Zainuddin., \& Atok, R. (2017). Penguatan Karakter Rasa Ingin Tahu Dan Peduli Sosial Melalui Discovery Learning. Jurnal Teori dan Praktis Pembelajaran IPS, 2(2), 27-36.

Guthrie, K. L \& Fritz, M. R. (2017). Value Clarification: Essential for Leadership Learning. Journal of Leadership Education 16(1), 47-63.

Haidar, M. (2017). Peran Pendidikan Luar Sekolah Dalam Penguatan Pendidikan Karakter. Seminar Nasional PendidikanFakultas Ilmu Pendidikan Universitas Negeri Malang.

Husu, J., \& Tirri, K. (2007). Developing Whole School Pedagogical Values-A Case of Going through the Ethos of good Schooling. Teaching and Teacher Education, 23(4), 390-401.

Kahil, R., \& El Hassan, K. (2005). The Effect of “Living Values: An Educational Program”” on Behaviors and Attitudes of Elementary Students in a Private School in Lebanon. Early Childhood Education Journal, 32(2), 81-90. https://link.springer.com/article/10.1007/s10643-005-0028-0.

Larkin, M. J. (2001). Providing Support for Student Independence Through Scaffolded Instruction. Teaching Exceptional Children, 34(1), 30-34. https://journals.sagepub.com/doi/pdf/10.1177/004005990103400104?

Wardono., Waluya, B 1, Kartono., Mulyono., \& Mariani, S. (2017). Development of Innovative Problem Based Learning Model with PMRI-Scientific Approach Using ICT to Increase Mathematics Literacy and Independence-Character of Junior High School Students. International Conference on Mathematics, Science and Education. https://iopscience.iop.org/article/10.1088/1742-6596/983/1/012099/pdf.

Masruri, M. S., \& Mursetyadi, Y. S. 2014. Keefektifan VCT Dalam Pembelajaran Sejarah untuk Meningkatkan Nilai Nasionalisme, Demokrasi, dan Multikultural. Jurnal Harmoni Sosial, 1(1), 71-82.

Mehlig , L. M., \& Milson, A. J. (2002). Elementary School Teachers' Sense of Efficacy for Character Education. The Journal of Educational Research, 96(1), 47-53.

Nasution, S. H. (2018). Pentingnya Literasi Teknologi Bagi Mahasiswa Calon Guru Matematika. Jurnal Kajian Pembelajaran Matematika, 2(1), 14-18.

Ozturk, C., dkk. (2011). Efficiency of Social Studies Integrated Character Education Program. Educational Sciences: Theory \& Practice, 11(2), 854-859.

Prestwich, D. L. (2004). Character Education in American Schools. School Community Journal, 14(1), $139-150$.

Putri, N. A. (2011). Penanaman Nilai-Nilai Pendidikan Karakter Melalui Mata Pelajaran Sosiologi. Jurnal Komunitas, 3(2), $205-15$.

Siregar, Y. E. Y., Zulela, M. S, Prayuningtyas, A. W, Rachmadtullah, R., \& Pohan, N. (2018). Self Regulation, Emotional Intelligence With Character Building In Elementary School. Proceedings of the Annual Civic Education Conference (ACEC 2018), 215, 314-318.

Rini, A. R. P. (2012). Kemandirian Remaja Berdasarkan Urutan Kelahiran. Kemandirian Remaja, 3(1), 61-70.

Rochani, R. P. (2017). Pengembangan Social Skill Sekolah Dasar melalui Teknik Pembelajaran VCT (Value Clarification Technique). Dwijacendekia: Jurnal Riset Pedagogik, 1(2), 70-78.

Scheetz, N. A \& Easterbrooks, S. R. (2004). Applying Critical Thinking Skills to Character Education and Value Clarification Student Who Are Deaf or Hard of Hearing. American Annals of the Deaf, 149(3), 255-263. 
Singh, B. (2019). Character Education in the $21^{\text {th }}$ Century. Journal of Social Studies, 15(1), 1-8.

Soetantyo, S. P. (2012). Peranan Dongeng Dalam Pembentukan Karakter Siswa Sekolah Dasar. Jurnal Pendidikan, 14(1), 4551.

Sulastri., Budimansyah, D., \& Sopandi, W. (2015). Implementing Value Clarification Technique to Improve Environmental Awareness among PreService Chemistry Teacher. International Conference on Sociology Education. https://doi.org/10.2991/icse-15.2016.41

Sumliyah. (2017). Efektivitas Pendekatan Value Clarification Technique Berbasis Karakter Kemandirian Pada Keterampilan Pemecahan Masalah. Eduma (Mathematics Education Learning and Teaching), 6(1), 1-31.

Susanto, H., Sa'dijah, C., \& Gipayana, M. (2016). Pengaruh Penggunaan Metode Guided Inquiry dan Gaya Berpikir terhadap Hasil Belajar Kognitif Kelas V. Jurnal Pendidikan: Teori, Penelitian, dan Pengembangan, 2(9), 1202-1211.

Tannir, A., \& Al-Hroub, A. (2013). Effects of Character Education on The Self-Esteem of Intellectually Able and Less Able Elementary Students In Kuwai.” International Journal of Special Education, 28(1), 47-59.

Tarigan, J. M. (2019). Penerapan Model Pembelajaran Value Clarification Technique menggunakan Metode Cerita untuk Meningkatkan Hasil Belajar Agama Kristen Siswa Kelas III SD Negeri 043935 Simpang Katepul Kabupaten Karo. Jurnal Ilmiah Kohesi, 3(1), 31-41.

Wening, S. (2012). Pembentukan Karakter Bangsa melalui Pendidikan Nilai. Jurnal Pendidikan Karakter, 2(1), 55-66.

Wijaya, R. S. (2015). Hubungan Kemandirian dengan Aktivitas Belajar Siswa. Junal Penelitian Tindakan Kelas Bimbingan Konseling, 1(3), 40-45. 